\title{
Religious-Ecocentrism Sustainability Accounting: Beyond Utopia towards Universe Sustainability
}

\section{Gusti Ayu Agung Omika Dewi}

Universitas Pendidikan Nasional, Jl. Bedugul No.39, Sidakarya, Denpasar Selatan, Kota Denpasar, Bali 80224, Indonesia

omikadewi@undiknas.ac.id

\section{ARTICLE INFO}

Article history

Received 3 January 2021

Revised 18 April 2021

Accepted 25 April 2021

Keywords

Religious Ecosentrism;

Sustainability Accounting;

Utopian;

Universe Sustainability .

\begin{abstract}
This article aims to construct a research methodology in the field of Sustainability Accounting (SA) which refers to the concept of deep ecology based on eco-centrism as well as a religious holistic based on universal values of religious teachings. The construction was carried out to "revive" SA through an ecosophical philosophy combined with the values of religious teachings, so that $S A$ can rediscover its spirit, soul, or identity, which places the interests of all beings into one unity with self-interest. The construction results found a new methodology, namely Religious-Ecocentrism which can arouse human consciousness at the highest level beyond the Utopian method which views the implementation of $S A$ as referring to ecological ethics based on infinite love for all God's creatures in order to realize universe sustainability.
\end{abstract}

This is an open access article under the CC-BY-SA license

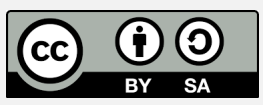

\section{Introduction}

Various multidimensional crises that are global in nature are currently hitting the world in all aspects of life without exception that occur due to environmental pollution and uncontrolled exploitation of nature through high-technology. The imbalance of power is seen as the cause of the energy, food and economic crisis on access to natural resources as well as high quality products [1]. The main causes of these crises are policies and development strategies that are not pro-people and not environmentally friendly, thus providing opportunities for business actors to exploit nature arbitrarily. As a result, the environment and all inherent natural resources are exploited and sacrificed by business actors in order to realize massive economic growth and maximum profit for the company. This condition then triggers the emergence of the concept of Corporate Social Responsibility (CSR), which in the context of accounting is known as sustainability accounting. Sustainability Accounting (SA) is conceptually interpreted as a tool that companies use to make company look more sustainable, where there has been a shift in the company's accounting system that has shifted from "traditional accounting" to "modern accounting", which focuses not only on economic information, but also social and environmental information. Therefore, with this transformation, the company's business activities have also undergone a change, where the impacts considered in making decisions include financial impacts, social impacts, and environmental impacts. 
The emergence of the concepts of CSR and SA has prompted companies to compete in declaring themselves as the most responsible company, most concerned with social and environmental conditions to create the impression that they are a "sustainable" company. Value creation in a company is often done through the SA mechanism so that the company becomes more sustainable, where the measurement used refers to the Triple Bottom Line (TBL) concept [2]. In accordance with this definition, the history of modernism shows that most companies (organizations) have implemented SA only at a surface level (material or physical) which is anthropocentric in nature. Why is that? Because SA in practice so far refers to the concept of the TBL which is described through 3P, namely Profit (Economy), People (Social), and Planet (Environment) and is analyzed using theories including Legitimacy Theory. So, doesn't the 3P concept and the Legitimacy theory used to analyze SA seem only as a camouflage to hide the true "motive" of the company so that it remains "sustainable" and has a positive image in the eyes of the community? This anthropocentric implementation of SA considers that humans are the center of all values and considers nature as a tool to create value for humans so that it leads to acts of oppression against nature arbitrarily.

The postmodernism view appears to convey a counter-narrative by using the Utopian method in reconstructing the accounts used in SA as an effort to save (maintain sustainability) species including humans themselves from extinction [3]. However, is Utopian already the right method to analyze SA? The purpose of this article is to present the development of a methodology in the field of SA which refers to the concept of deep ecology based on ecocentrism as well as a religious holistic based on universal values of religious teachings. Capra (1996) in his article entitled Deep Ecology: A New Paradigm states that anthropocentric is a shallow ecology which has a different perspective from deep ecology. Shallow ecology is an anthropocentric which sees humans as being above or outside nature, as the source of all values, and considers nature only as an instrument, or applies value to nature. Deep ecology does not separate humans from the natural environment, nor does it separate everything from the natural environment. Deep Ecology does not see the world as a collection of isolated objects but as a network of phenomena that are interconnected and fundamentally interdependent. Deep ecology recognizes the intrinsic values of all living things and views humans as only a special part in the web of life. This new ecological paradigm implies a conforming ecologically oriented ethic. The ethical framework linked to the old paradigm is no longer sufficient to address some of the major ethical issues of our day, most of which pose threats to non-human forms of life. The implementation of SA in the era of modernism according to a shallow ecology view has resulted in the separation of accounting from "God", because the main focus is self interest or group interest. So that accounting is considered dead because it has separated from God as the source of its "soul" or "spirit". The Utopian method used in accordance with the postmodernism view has not been able to find any separation of accounting from God itself, so the construction of this SA methodology is carried out at a level beyond the Utopian method.

The construction of the SA methodology at the beyond postmodernism level is indeed important to do because there has been a failure to understand the value substance of SA. As stated by Mulawarman (2019) in the context of Agricultural Accounting there 
has also been a failure to understand the essence of value, sanctity, and prophetic image, both in the past, present, and future, so that accounting and agriculture experience domination and coercion over the construction of historical algorithmic trajectories continuously [4]. The complex and acute historical failure then raises the image of the truth of accounting and agriculture that cannot be denied and "must" be implemented according to the ideas of secular capitalism and neoliberalism, which seek to dichotomy values that are sacred (God and Religion) such as science and technology in worldly practices, including accounting and business practices. The domination of secular capitalism and neoliberalism is getting stronger along with the presence of the 4.0 industrial revolution which also seeks to "negate God" and considers that civilization still exists today without God's power. Since the era of secularism, accounting is considered dead because the human side is stronger than the divine side [4]. This situation is in accordance with what Harari (2016) stated that humans have become Homo Deus [5].

The separation of accounting from agriculture is in line with the separation of accounting from God which is marked by the condition that accounting is becoming increasingly controlled by Capitalism based on Nihilism. In this context, accounting assumptions have been changed to become the language of economics, the language of business, to satisfy personal egos, and ignore common interests. This situation then prompted Mulawarman (2019) to re-purify accounting through tazkiyah (re-purification) to reach Scientia Sacra, which is sacred knowledge which is located at the core of revelation and is the center of the circle covering and explaining religious religiosity. In essence, according to Nasr (2003) Scientia Sacra [6] can only be achieved through the action of the universal human being, Insan Kamil, a Muslim figure who always reflects Allah's Name, Nature and Light, in the space and time of civilization, including accounting and agriculture in it [4]. The conditions that occur in agricultural accounting are similar to those in SA, which are considered dead because they experience separation from God as the source of their "soul or spirit". The history of modernism shows that the main focus of sustainability accounting is shallow ecology-based anthropocentrism which prioritizes selfinterest or group interest.

\section{Method}

The method used in this study is a literature review as an effort to find a suitable methodology to construct the concept of SA. The methodological construction is carried out by referring to the concept of deep ecology based on eco-centrism as well as religious holistic based on universal values of religious teachings, namely love without limits. The result is the Religious-Ecocentrism methodology that is used to "revive" SA so that it can rediscover its spirit, soul, or identity.

\section{Results and Discussion}

\subsection{Sustainability Accounting and The Downfall of Modernism}

Tilt argues that SA is a sub-category of financial accounting that focuses on disclosing information about an organization's non-financial performance to stakeholders [7]. The application of SA has many benefits for companies or organizations, including as a tool to make the company more "sustainable" or sustainable. By applying the concept of SA, 
company management has linked the company's business strategy with a sustainability framework so that the company will consider more about social and environmental impacts that refer to the Triple Bottom Line concept, not only focusing on financial impacts. Elkington packs the TBL concept into three key references (3P), including profit, planet, and people, meaning that companies (organizations) must act for sustainability by paying attention to economic (profit), environmental (planet), and society (people) [8]. However, in fact, there are still many companies that use sustainability accounting as a "mask" with its $3 \mathrm{P}$ concept changing "sustainability" to "profitability". What's more, if the 3P concept is only used as a kind of "lipstick" or "blush" for companies trying to cover up the negative impact of the business activities they carry out. This condition is of course contrary to the true essence of sustainability accounting, which is trying to accommodate the interests of different stakeholders.

Furthermore, it is stated that the theory that is often used to analyze the implementation of SA according to the modernism view, is the Legitimacy theory. Legitimacy theory implies a conformity between the activities carried out by a company with the values or norms held by the community where the company operates. The use of Legitimacy theory in previous accounting research can be seen from research conducted by Dewi and Dewi (2017) which examines Green Banking, CSR and Going Concern in banking sector companies in Indonesia [9]. The results of this study found that the implementation of Green Banking can strengthen the interaction between CSR and Going Concern. So, according to the view of the Legitimacy theory, The concern of banking companies on the Indonesia Stock Exchange can be seen from the implementation of Green Banking, which in fact can strengthen the relationship between CSR implementation and the company's going concern (sustainability). This research is expected to contribute to the results of this study to assist banking management in implementing Green Banking in relation to the implementation of CSR as an effort to create a good image in the eyes of stakeholders. Legitimacy theory holds that the company (organization) will attempt to carry out whatever action is deemed necessary in an effort to maintain a good image as a legitimate company in the eyes of stakeholders [10].

Further search regarding usage Legitimacy theory in analyzing SA shows that there is a "motivation" that underlies companies to disclose social and environmental information through SA mechanisms [11,12]. There are three reasons that motivate companies to practice sustainability reporting. First, non-compliance, which means that as a corporate strategy that ultimately brings profit [13]. Second, in compliance which means as a form of obligation because its implementation is forced by regulations. Third, beyond compliance as a form of awareness, which is based on the feeling that the company is part of the community. If traced back, The use of legitimacy theory will bring a tendency that the implementation of sustainability accounting by companies is not for environmental or social interests, but only for the benefit of the company itself. Legitimacy theory which states that companies report social and environmental information as a process of legitimacy for all their activities will lead us to understand that the implementation of sustainability accounting is to perpetuate the company's efforts to maximize profits so that the company's financial performance can increase. 
In simple terms, it can be said that, based on the legitimacy theory, the company's motivation to implement it can be seen SA namely as a form of obeying the rules, realizing competitive advantage, complying with the rules of loan contracts, fulfilling community expectations, legitimizing company activities, and to attract investors [14]. Based on this explanation, it can be seen that the use of legitimacy theory will be in line with the view of modernism which is full of capitalistic values, which assumes that the implementation of SA is carried out by companies because there is an element of compulsion through economic considerations and the provisions required by regulations. In the context of environmental management, the mistake of the human perspective that considers himself not a part of nature or part of the entire ecosystem causes humans to not realize that ecological damage due to environmental management that relies too much on human interests (anthropocentric) will ultimately confront humans themselves. Anthropocentric ethics has received a lot of criticism and criticism because it places humans as biological humans who have a "life to life" perspective and even more narrowly "live for humans". The environmental crisis is thought to occur because human behavior is influenced by anthropocentric perspectives. Such exploitative, destructive and indifferent behavior patterns are thought to be rooted in a perspective that only cares for human interests. Anthropocentric ethics has received a lot of criticism and criticism because it places humans as biological humans who have a "life to life" perspective and even more narrowly "live for humans". The environmental crisis is thought to occur because human behavior is influenced by anthropocentric perspectives. Such exploitative, destructive and indifferent behavior patterns are thought to be rooted in a perspective that only cares for human interests. Anthropocentric ethics has received a lot of criticism and criticism because it places humans as biological humans who have a "life to life" perspective and even more narrowly "live for humans". The environmental crisis is thought to occur because human behavior is influenced by anthropocentric perspectives. Such exploitative, destructive and indifferent behavior patterns are thought to be rooted in a perspective that only cares for human interests.

Anything that humans can do to nature, as long as it does not harm human interests, as long as it does not have an impact that is detrimental to human interests (in the sense of short-term interests) Human moral obligations and responsibilities to the environment solely for the sake of fulfilling the interests of fellow profit-oriented humans. Profit, which is the orientation of capitalism, has resulted in damage to the balance of human life by over-stimulating the development of economic potential and not contributing to increasing welfare, but resulting in decreased social conditions [15]. This is in line with what environmental activists say, Human Rights, and local communities who often state that the basic motive of all the CSR concepts offered is only used as a strategy for neoliberalism to continue to be able to necessitate oppressive capitalism [16]. Empirical evidence regarding the existence of capitalism hegemony can be seen in the research of Mulawarman and Kamayanti (2018) which shows how the neoliberalism project has forced accountants and standard setters to "surrender" because they are influenced by secular anthropology that relies on the concept of "self" as a result of the infiltration of Secular Western culture through education and educators as agents who find their legitimacy in state policies [17]. 
Currently, company management has implemented many SA in the company's business activities and is committed to disclosing the economic, social and environmental impacts of the company's business activities. The motivation for disclosing information related to CSR according to the view of legitimacy theory is primarily for sustainability purposes or also known as going concern. The key word for going concern according to Mulawarman (2019) is efficiency, which is a mandatory implementation of agency theory that focuses on the interaction between principal and agent in terms of wealth interests. So, for the purpose of maximizing the principal and agent's wealth in agency theory, the company will take any action to maintain the company's image through legitimacy theory. With this concept, it can be seen again that "sustainability" or "going concern" under the perspective of Agency Theory, Legitimacy Theory and all its derivatives only prioritize the interests of shareholders (owners of capital) and tend to "put aside" the interests of stakeholders. As stated by Kusdewanti (2016: 77) that Agency Theory creates ideological realities that lead to Legitimacy for economic orientation, because it has been "possessed" by neoclassical ideas so that the reality that emerges is the rationality of individualism of actors to create "welfare" through (rhetoric) contractual equilibrium. Why does this happen? Once again the cause is because the implementation of SA has "negated" God so that egocentrism is put forward rather than collective interest [18].

The history of modernism notes that the concept of SA in a global context first surfaced in the 1970s. Crowther (2000) states that social accounting includes a fairly broad aspect of company performance and can accommodate the interests of many stakeholders. The aspect in question consists of a focus on shareholders, a focus on interaction with the community, and a focus on the environment (ecology) [19]. At the international level, actually many companies have implemented various social and environmental reporting standards in an effort to show that their business is responsible [20]. Various standards are used as a basis for implementing sustainability accounting, including: (1) Global Reporting Initiative's (GRI), is a company sustainability report guide to support the Sustainable Development Goals (SDG's) initiated by the UN in 1997 through the Coalition for Environmentally Responsible Economies (CERES) and UNEP; (2) Accountability's (AA1000) standard, is a company reporting guide that conforms to the concept of "Triple Bottom Line" (profit, people, planet) which was initiated by John Elkingtong in 1998; (3) Social Accountability International's SA8000's Standard; (4) ISO 14000 Environmental Management Standard; (5) ISO 26000 Guidance Standard on Social Responsibility and the most recent is Sustainable Development Goals or SDG's. As for the context in Indonesia, the implementation of SA is regulated in Law no. 40 of 2007 concerning Limited Liability Companies (PT) and also regulated in Financial Accounting Standards (SAK).

The existence of these various standards is not sufficient to solve problems related to sustainability. Why is that? Because the standard setters involved in the preparation of these various standards seem to prioritize personal and group interests more than universal interests. For example, SDG's in relation to sustainability received criticism from the Club of Romeo who doubted the SDG's vision was considered to have transformational reach, but the implementation of the SDG's 2030 Agenda is almost impossible to achieve, especially if the orientation is on the success of the eleven social and economic goals. The impact of accelerating growth does provide a solution to the achievement of socio- 
economic goals but at the expense of the environment and pushes the planet's boundaries into high-risk zones (Mulawarman, 2019: 18). The Club of Romeo then offers an alternative so that the implementation of the 2030 Agenda can be achieved, where the condition is that conventional growth must be replaced by policies that prioritize wellfare and wellbeing by placing ecological and social goals at the forefront of policy making.

Furthermore, regarding the objectives of sustainability on the SDGs, Capra $(1988,389-$ 403) offers a more paradigmatic solution called the Systemic Wisdom View of Life based on an integral awareness of the essential interrelationships and interdependence of all physical, biological, psychological, social and cultural phenomena, as well as an economy that also cannot be separated from the integrality of the system. In this system, humans and social organizations in their interactions must be connected to the surrounding environmental ecosystems which are the support of dynamic and non-linear life [21]. The two alternative proposals from the Club of Romeo and Capra, according to Mulawarman (2019: 20), cannot yet be a clear explanation in the context of sustainability. Why is that? Because once again the two proposals are not inspired by the existence of a "divine element", so that the proposal has not really made sustainability accounting a "life again".

\subsection{Sustainability Accounting and The Emergence of Postmodernism}

Currently we are faced with a situation that modernism has ruled the world in various fields of life without exception including accounting. A new view emerged that brought extraordinary changes in the world of accounting, where this view is known as the postmodernism paradigm. The postmodernist paradigm can be seen as a solution to the problems arising from capitalists, because it can see the various relationalities of accounting science and practice itself. The paradigm of postmodernism is very much against the metanarative view (neoliberalism thought) which claims to have found the truth about the social world. On the other hand, the postmodernism paradigm always puts forward the use of various approaches so that problems can be answered comprehensively. Postmodernism also provides space to communicate openly, democratic, cooperative and demonstrative in the discourse to propose truth in a better and dynamic social order, in various disciplines including accounting. More specifically, SA in the frame of postmodernism is opposite to modernism which aims to expand and shape a diversity of perspectives, so that sustainability accounting is no longer co-opted in one dominant perspective. Kamayanti (2020: 35) states that the saturation of modern assumptions (positivism, interpretivism, and criticism) raises a postmodernist paradigm with the assumption of the absence of concrete reality [22].

Efforts to define SA within the framework of postmodernism will result in a "deadlock" because postmodernism rejects a single truth, both truths resulting from the paradigm of positivism, interpretivism, and criticism. For example, we can look at previous accounting research conducted by Dewi (2010) regarding SA. The research found that the reality of "sustainability" is understood in three forms, namely pseudo sustainability; obligatory sustainability (mandatory sustainability); and humanism sustainability (humanist sustainability). The findings of this research, in the postmodernist paradigm, are considered unable to explain the reality of "sustainability" completely and completely, and there are still capitalist values in it. Previous research in the postmodernist paradigm carried out by Gray and Milne (2018) aims to offer a counter-narrative because it views 
humanity as the root cause of most of the current species extinction. So it can be said that actually humans are also in an endangered situation and that human extinction is considered a good thing. Humans are said to be destructive because they have tried in various ways to issue various (western) narratives that seem to care about nature and the environment, but in fact have oppressed the natural environment along with the various species in it. Gray and Milne (2018) came up with a new paradigm, namely postmodernism to construct SA using the Utopian method through the imagination of a better world in the future. This postmodernism view has led to a counter-narrative of the current conditions to free accounting, especially SA from the hegemony of capitalism. However, the counternarrative discussed in Gray and Milne's (2018) article has not considered the aspects of spirituality or religiosity which play an important role in constructing SA, in order to animate, give "spirit", and give identity to SA. This postmodernism view has led to a counter-narrative to the current conditions to free accounting, especially SA from the hegemony of capitalism. However, the counter-narrative discussed in Gray and Milne's (2018) article has not considered the aspects of spirituality or religiosity which play an important role in constructing SA, in order to animate, give "spirit", and give identity to SA. This postmodernism view has led to a counter-narrative to the current conditions to free accounting, especially SA from the hegemony of capitalism. However, the counternarrative discussed in Gray and Milne's (2018) article has not considered the aspects of spirituality or religiosity which play an important role in constructing SA, in order to animate, give "spirit", and give identity to SA.

Previous accounting research which also used the postmodern paradigm was carried out by Dewi (2014) who reconstructed the CSR reporting model using the Hindu philosophy, Tri Hita Karana (THK) [23]. Reconstruction resulted in four aspects of accountability, namely the economy, measured using direct economic indicators and indirect economic indicators; social, measured using indicators; labor practices and occupational safety, human rights, empowerment of local communities, and product responsibility; environment, measured using environmental indicators (raw materials, energy, water, emissions, effluent and waste, biodiversity); and spiritual, measured using spiritual indicators (obedience to natural laws), devotion to fellow humans, and sacrifice to nature (environment). Dewi's research (2014) has considered the spiritual aspect, but it is only limited to the nature of humans as homo-religious beings. Based on the above explanation, apart from all the advantages, the postmodernism paradigm also has weaknesses. The weakness of the postmodernism paradigm lies in its unstructured, nonformal, irregular approach and usually does not conform to scientific principles. Reality in the postmodern viewpoint is described by Rosenau (1992), as assumptions about the author, reader, text, subject, history, and theory [24]. Postmodernism holds that the goal of obtaining truth is not the perspective of the main goal of science. Postmodernism rejects theory because it reflects truths which in the context of social science have a very theoretical character. Truth in postmodernism is a plurality, then all monopolistic claims to truth are completely opposed by postmodernism (Kamayanti, 2020: 36-37). 


\subsection{Postmodernism, the Utopian Method, and the Urgency of Alternative Paradigms}

Today's accounting language or capitalism accounting language, or the language of profit and loss. So every word in capitalism accounting means profit or loss. This concept is of course contrary to postmodernism which views accounting as not just profit or loss [25]. Postmodernism is the antithesis of modernism that answers problems that cannot be solved by human reason and has a very anti-establishment nature (status quo). Featherstone (1988) concludes that postmodernism is a method of critical analysis that seeks to dismantle the anomalies and myths of modernism paradigm, open irony, linkages between texts and paradoxes, try to find a theory of postmodern society, and describe it in the social realities that exist in contemporary Western society today [26]. Today we are faced with the challenge that Capitalism and Liberalism have changed faces for a long time, where liberalism has adapted to become Neoliberalism. Our world is no longer in the era of modernism, humanism, secularism, democracy, because it has entered the world of postmodernism, posthumanism, postsecularism, postdemocracy, and even post of everyting [27].

The challenge for our society is self-sovereignty, land, food, energy, and all the sovereignty needed as an independent, independent, and sovereign nation in our own country with a new universe. Mulawarman mentioned all these challenges as Universal Colonialism which is everywhere, whether physical, material, even values, conscience and has been considered as universal consciousness, awareness of universal truth. It is also this Universal Colonialism Challenge that is currently being faced by SA in realizing the goal of sustainability. Universal Colonialism views the truth, as the foundation of old Capitalism and Communism, namely empiricism, concrete, material, for self-interest and fulfills the rules for the growth of Social Darwinism. The ease with which Universal Colonialism is designed from the present truth, here and in accordance with the human being, no longer Allah SWT [27]. Based on this explanation, it can be seen that Universal Colonialism emerged as a challenge in society, specifically in SA to thwart the achievement of the goal of sustainability as a result of the strengthening of the human self that tries to eliminate divine truth.

Ideally, the objective of implementing SA is to create a universe of sustainability, where in order to achieve this goal, an appropriate methodology is needed. Gray and Milne (2018), through the postmodernist paradigm, offer a narrative through the Utopian method that comes from imaginative thinking as an effort to find solutions to solving a problem. The narrative offered is in the form of new accounts that help humans to imagine things that are currently unthinkable. When viewed in the context of SA, it can be seen that Gray and Milne (2018) offer a narrative as the antithesis of the existence of a western narrative that is anthropocentrism. in the form of the discourse "Will humans become extinct along with the extinction of species caused by the act of humans themselves who exploit nature without limits?" Of course, this condition will thwart the achievement of sustainability goals. Therefore, to change the future we must change the story, and replace it with a new myth, to change our world view that will clearly resonate with many indigenous peoples, and one that seeks to generate hope and optimism.

This Utopian method, in my view, cannot yet provide solutions to problems related to SA. Why is that? Because the Utopian method's attempt to change the future is based 
solely on an imaginative narrative that doesn't necessarily lead people to believe it. According to Kamayanti (2020: 39), knowledge that is built from a research will ultimately affect our lives deeply. So, if an assumption is believed to be true and science is built on that assumption, of course the built-in science reflects the truth of the assumption. The method in the end is not just a research tool. Methods rooted in a particular paradigm will form a particular civilization. In retrospect, one point is not addressed in all the assumptions of the thinking of Burrell and Morgan (1979), Chua (1986), and Sarantakos (1994) are assumptions about God as the embodiment of secular modernity [28-30]. If God is not "involved" in any science, including accounting, what will the future be like for accounting? Mulawarman (2010: 164) explains how assumptions about God, for example placing Islam as a specific paradigm and separate from other paradigms [31]. Therefore, it is necessary to have an urgency to use a paradigm that believes that God must exist in the development of science. Why is that? In accordance with the personality of the Indonesian nation, which has various religions, ethnicities, customs, cultures, races and so on, it is united in the foundation of the state, namely Pancasila, which clearly states the belief in the existence of God.

Basically, the existence of a science cannot be separated from the existence of God, including the science of accounting itself. If God does not exist, how can man exist, and how can science exist? In the context of SA, this thinking can be understood that the goal of sustainability can only be achieved if the existence of God is the source. Why is that? The key word for achieving a universe of sustainability is life balance, justice and shared prosperity. This is of course very much in accordance with the personality of the Indonesian nation, which, although different, is still one as stated in the motto of Unity in Diversity, Tan Hana Dharma Mangrwa. This motto has different meanings but still one, there is no dual truth, where the "one" Dharma (truth) is God. If SA has been implemented according to these principles, there will be no more dominance of economic aspects compared to social and environmental aspects, because everything has been centered on spiritual or religious aspects with God as the source, so that universe sustainability can be realized.

\subsection{Sustainability Accounting, Shallow Ecology, Deep Ecology}

Modern is a symbol of the abandonment of the past that is not modern which emphasizes the closeness to supernatural or even supernatural powers such as theology or religion, entering into a better present. Modern views that forces outside humans no longer play a significant role in humans. But man is the center of everything. General understanding of modernism like that then pushed into accounting, namely Modern Accounting. Modern accounting is currently only and always has the connotation of an "instrumental" process for the company's business activities. It has even become an inevitable adage. Accounting in general (almost) is always connoted as a "tool" for recording money flows and delivering financial information in the realm of business activities [32]. This connotation also occurs in the realm of SA, which is often seen as a tool to create a corporate image so that the company gets a "sustainable" impression in the eyes of its stakeholders. What, in fact, is the cause of these various connotations?

The main cause is the exclusion of "God" in the scientific world, especially in accounting because God, religious values and human (subjective) souls are the center and 
the meeting of God's "values" and awareness of the absolute truth of the holy book, are no longer allowed to enter the realm of the universe and social reality scientifically. Even the Absolute reality and faith are considered irrelevant, because modernism already has the legitimacy of another theological "faith and salvation", namely material progress made possible by the market and science-technology. Accounting (as part of Economics) goes hand in hand to form a new theology, for the miraculous way the market works through The Invisible Hand for welfare, changing personal greed (visible in the certainty of bottom line profit, linearity equity, and the availability of progressive cash) becomes social-virtue (general goodness), which leads to scientific-technology rationality developed for the benefit of profit. Capitalism is the end of the technical interests of positivism and empiricism in the real world (Mulawarman, 2013: 153). And how is the result? Our world is currently hit by various multidimensional crises that culminated in Covid-19 which has ravaged world civilization in various sectors. This crisis is referred to as a complex and multidimensional crisis that touches all aspects of life such as health and livelihoods, environmental quality and social, economic, technological and political relations. This crisis for him is a crisis in the intellectual, moral and spiritual dimensions, an unprecedented crisis in the historical record of mankind.

Capra (1996) argues that the multidimensional crisis is actually rooted in the wrong way in which humans perceive themselves as anthropocentric, which results in wrong behavior towards nature. Humans mistakenly view nature and mistakenly place themselves in the context of the entire universe. Anthropocentric is a shallow ecology which has a different perspective from deep ecology. Shallow ecology or anthropocentric sees humans as being above or outside nature, as the source of all values, and considers nature only as an instrument, or applies value to nature. Deep ecology does not separate humans from the natural environment, neitherdoes not separate things from the natural environment. Deep Ecology does not see the world as a collection of isolated objects but as a network of phenomena that are interconnected and fundamentally interdependent. Deep ecology recognizes the intrinsic values of all living things and views humans as only a special part in the web of life. This new ecological paradigm (deep ecology) implies a suitably ecologically oriented ethic. When viewed in the context of SA, deep ecology can be used to find a bright way to unite with nature in order to realize the goals of sustainability.

\subsection{Boundless Love: Perennialism of Holistic Religiosity Towards Universe Sustainability}

The development of modern science has met various dead ends after the enlightenment century which then triggers to retrace the problems of knowledge. Not all consider that modern science is a "deadlock" but for those who realize that the consequences have led to destruction both ethically and humanistically, this is worthy of being called a "deadlock" (Kusdewanti, 2016: 22). When viewed in the context of SA, the "deadlock" referred to here is due to SA, such as agricultural accounting which was initiated by Mulawarman (2019) which has experienced "death" because it has separated from God as the source of its "soul" or "spirit". It is said thus, because the existence of modern science has made SA "lost" in a dead end because it is complacent with the glitz of egocentrism and anthropocentrism that promise unlimited wealth and prosperity. Therefore, it is necessary to have a way to build a new concept through the construction process as an effort to 
"revive" SA. This construction is carried out through the values of religious teachings, especially regarding love, as a light of divine guidance, so that SA can rediscover its spirit or soul, which will put the interests of all beings into one unit with the aim of sustainability. It is necessary to have a way to build a new concept through the construction process as an effort to "revive" SA. This construction is carried out through the values of religious teachings, especially regarding love, as a light of divine guidance, so that SA can rediscover its spirit or soul, which will put the interests of all beings into one unit with the aim of sustainability. It is necessary to have a way to build a new concept through the construction process as an effort to "revive" SA. This construction is carried out through the values of religious teachings, especially regarding love, as a light of divine guidance, so that SA can rediscover its spirit or soul, which will put the interests of all beings into one unit with the aim of sustainability.

The religious teaching that is used as the basis for constructing the methodology is love which is universal and holistic. Perennialism religious philosophy, believes that every religion in the world has a single and universal truth which is the basis for all religious knowledge and doctrine. The idea of perennialism has existed since ancient times and can be found in various world religions and philosophies. The teaching of love is a universal teaching that exists in all religious teachings. Charity is the sacred mission of all world religions and love should become a real practice in everyday life. In Indonesia alone there are 6 religions that are officially recognized by the government. If we trace back the universal values contained in the teachings of 6 religions, namely Hinduism, Buddhism, Islam, Confucianism, Catholic Christianity and Protestant Christianity, it can be seen that the universal concept that exists in all religious teachings is Love Without Borders. In the context of SA, by practicing love for all living beings without limits, we will be able to create a balance of life and common prosperity towards Universe Sustainability.

The following will describe some of the teachings of Love from each religion [33]. The Buddhist teachings of love, are described in the Mettā Sutta, Khuddakapāñha, Khuddaka Nikāya, which can be seen in the following quotations:

"Love is like a mother who risked her life, protected her only son. Thus with all beings, the mind of infinite love is developed, upward, downward, and around, without hindrance, without hatred and enmity. "

In Buddhist belief, love is also called metta. The love taught by the Buddha is universal love. It is different from the love that is felt when we like the opposite sex which has the nature of attachment or the desire to have eternal possessions, is influenced by worldly emotions, and there is a sense of selflessness and lust. Meanwhile, universal love is love for all beings, such as fellow humans, animals, insects, plants, parents, siblings, friends, even enemies or demonic creatures.

The Teachings of Love for Catholic Christianity and Protestant Christianity can be seen in the following quotations regarding the Law of Love [33]: 
"Love the Lord your God with all your heart and with all your soul and with all your mind; that is the first and foremost law. And the second commandment that is the same as it is: love your neighbor as yourself "(Matt. 22: 37-39).

The quote from the bible means that the law of love contains two important elements, namely that humans must love God with all their power and the other element is that love for God is concretized with love for others because it is also written that loving others means loving God. From this it appears that love for others has the same degree as love for God.

The teachings of love for Catholic Christianity and Protestant Christianity can also be seen in the Bible quotation regarding the origin of love as follows:

"Love / love comes from God. God is love. Love is one of the main characteristics of Allah. Allah has gifted us with the capacity / ability to love / love, because we are created in His image. This capacity to love is one proof that we are created in the image of Allah "(John 3:16)

The quote means that in fact God (Allah) is love and is the origin of love, where humans who are created in God's image should have the ability to love or love other creatures created by God.

The teaching of Confucian Religious Love can be seen in the quote from the Book of Mengzi Chapter VI A. 6 verse 7 as follows:

"As for the compassionate heart, it shows the seed of Love, the shame and dislike shows the seed of awareness upholding the Truth, the respect and heeding it shows the seed of Morality, and the feeling of justifying and blaming it shows the seed. Wisdom. Love, Truth, Morality, and Wisdom are not things that are inserted from the outside in, but we already have them. But often we don't want to be introspective. So it says "Seek and you will find it, waste it and you will lose".

According to Mengzi's explanation, a great Confucian religious figure in the above quote means that if someone has compassion for others, then that person already has the seeds of love. Confucians believe that this true character is the seed that a human has from birth or even in the womb. So, in addition to humans having to develop a sense of love, humans must train and develop the seeds of truth, decency and wisdom, so that they become humans who have a perfect personality (Junzi). A person who already understands, lives and practices Love, Truth, Morality and Wisdom will gain trust (Xin) from God, others and the universe. In other words, humans are already in harmony or in harmony with God,

The teaching of love for the Islamic religion can be seen in the same context, the Prophet SAW also ordered to love creatures on the surface of this earth regardless of their religion, in his words it can be seen in the following quote:

"People who are compassionate, must be loved by Allah. So have love for every inhabitant of the earth, surely you will be loved by the inhabitants of the heavens, namely the angels. " (Narrated by Abu Daud). 
The above quote shows that affection in Islam is permanent, not temporary, valued and occupies an honorable, holy, and sacred position. It is further explained about the teachings of love and affection according to Islam in the following quote:

And look for what Allah has given you (happiness) in the land of the Hereafter, and do not forget your part of the (pleasure) of the world and do good (to others) as Allah has done good, to you, and do not do damage to (face) earth. Indeed, Allah does not like those who do damage.

The quotation means that humans have been gifted with happiness in the world and the hereafter, therefore humans should do good to others as God has done good to humans. Humans should also always take care of the universe and not do damage because people who do damage are not liked by Allah.

The teachings of love according to Hinduism are Tat Twam Asi teachings which can be seen in the following quote:

"Tat twam asi (Dewanagari: तत्त्वम् असि or तत्त्वमसि; IAST: Tat tvam asi, Tattvamasi) Alihaksara: tattvamasyādivākyena svātmā hi pratipāditah / neti neti śrutirbrūyādanṛtaì pāñcabhautikam //25//

Based on the quote, it can be explained that Tat Twam Asi is a Hindu concept originating from the Sanskrit language, meaning that "I am you and you are me and all creatures are the same", because in essence Atman makes life between me and you come from one source namely God. Tat Twam Asi is called a social teaching without boundaries because it can understand reality based on love and compassion which can unite the souls or souls of all living things and all of God's creation as the source of all sources of life in the universe. There will no longer be individual interests (self interest) or group interest (group interest), but become common interests (common interest). At this stage, the implementation of SA has reached the highest level of religious teachings which views that humans should always do good based on love for others and all of God's creation as God has bestowed compassion and good deeds on humans and all of His creation.

\subsection{New Methodology: Religious-Ecocentrism}

A methodological construction based on the beyond postmodernism view can be carried out by combining the values of religious teachings, namely unlimited love and the concept of deep ecology based on eco-centrism. The result is a Religious-Ecocentrism Methodology which can explain the true essence of SA itself. In the future, the ReligiousEcocentrism methodology is expected to be able to realize the goal of sustainability, namely universe sustainability. Borrowing the term used by Mulawarman (2008), SA in the view of modernism based on the Triple Bottom Line, Legitimacy Theory or SDG's concept is motivated by selfish love, which is love based on lust or desire to have implementation in the form of 'shareholder' and 'market' interests that create corporate hegemony, "push aside" the interests of stakeholders and "negate" the existence of God [34]. SA then metamorphosed beautifully into SA based on Religious-Ecocentrism which is motivated by boundless love, which seeks to balance the interests of different 
stakeholders, which according to Mulawarman (2008) includes management, employees, investors, creditors, suppliers, customers, consumers, society, including spiritual stakeholders, namely the Creator (Allah / God). "Aside" the interests of stakeholders and "negate" the existence of God. I don't agree with Mulawarman (2008) who made God the Stakeholders. In my view, God is the center or source of all kinds of interactions between the company and all related stakeholders. As for what is meant by love without limits is universal love aimed at all creatures, namely fellow humans, parents, siblings, friends, animals, insects, plants, and all creatures created by God. Love without limits is the main love is love for the Lord of the Universe. Love for Allah then emphasizes love for others and the natural environment. Love that is meant here is not selfish love which is only material in nature, but love in the material, mental and spiritual meaning, truly love or hyperlove (love that transcends). Love that transcends is a form of complete understanding of the company's interactions with its stakeholders based on mutual trust and honesty and eliminating suspicion and betrayal (Mulawarman, 2008). If the concept of sustainability is lived and practiced well, a balance of life, justice and mutual welfare can be realized. The implementation of SA will later actually be able to realize universal sustainability that can unite the interests of all creatures in the universe with God as the center or source to get to Universe Sustainability.

\section{Conclusion}

SA in the view of modernism, it is considered as a tool used by companies (organizations) to create an "image" as a "sustainable" company. This view is of course a wrong view, because SA is only understood at a physical or material level, thus forgetting the true "essence" of sustainability goals. SA, which has been frequently studied using the TBL concept, and analyzed using theories such as the Legitimacy theory which is claimed to be able to realize SDG's, in fact ultimately leads to a global multidimensional crisis. The postmodernist paradigm appears to make "improvements" to this condition, among others by offering counter-narratives using the Utopian method, as an effort to maintain the sustainability of species, including humans, from extinction.

However, the Utopian method has not been able to find the "main cause" of all problems related to sustainability accounting, because there is no complete "union" with nature and God. Therefore, it is deemed necessary to construct a SA methodology at the level beyond postmodernism beyond the Utopian method. The methodological construction is carried out by referring to the concept of deep ecology based on ecocentrism as well as religious holistic based on universal values of religious teachings, namely love without limits. The result is the Religious-Ecocentrism methodology that is used to "revive" SA so that it can rediscover its spirit, soul, or identity. Based on this concept, SA implementation will be able to unite the interests of all creatures in the universe, with God as the center or source. The Religious-Ecocentrism methodology is believed to be able to unite the thoughts of all religious communities in the world, so that there will be no individual interests (self interest) or group interest (group interest), but become a common interest (common interest) If the concept of SA is practiced properly, then a balance, justice and mutual prosperity can be realized towards Universe Sustainability. 


\section{References}

[1] Mulawarman AD. Nyanyian Metodologi Akuntansi ala Nataatmadja: Melampaui Derridian Mengembangkan Pemikiran Bangsa "Sendiri." J Akunt Multiparadigma 2013;4. doi:10.18202/jamal.2013.04.7189.

[2] Perrini F, Tencati A. Sustainability and Management Stakeholders: The Need for a New Company Performance Evaluation and Reporting System. Strateg Bus Environ 2006;15:296-308. doi:doi:/10.1002/bse.538.

[3] Gray R, Milne MJ. Perhaps the Dodo should have accounted for human beings? Accounts of humanity and (its) extinction. Accounting, Audit Account $\mathrm{J}$ 2018;31:826-848,. doi:https://doi.org/10.1108/ AAAJ-03-2016-2483.

[4] Mulawarman AD. Akuntansi Pertanian: A prophetic legacy. Yayasan Rumah Peneleh. Seri Media dan Literasi; 2019.

[5] Harari YN. Homo Deus: a Brief History of Tomorrow. Harvill Secker; 2015.

[6] Nasr SH. Science and Civilization in Islam. Chicago: ABC International Group; 2001. doi:10.1007/s13398-014-0173-7.2.

[7] Tilt C. Accounting and Accountant: Corporate Social Responsibility. Prof Perspect Corp Soc Responsib 2007. doi:10.1007/978-3-642-02630-0 2.

[8] Elkington J. Enter the Triple Bottom Line 2001;1:1-16.

[9] Dewi IGAAO, Dewi IGAAP. Corporate Social Responsibility, Green Banking, and Going Concern on Banking Company in Indonesia Stock Exchange. Int J Soc Sci Humanit 2017;1:118-34.

[10] Villiers C, Staden C. Can Less Environmental Disclosure Have a Legitimizing Effect? Evidence fromAfrica. Accounting, Organ Soc 2006;31:763-781.

[11] Parsa S, Kouhy R. Disclosure of Social Information by UK Companies-A Case of Legitimacy Theory. Glob Bus Econ Rev 2002:460-73.

[12] Tilling M. Refinements to Legitimacy Theory in Social and Environmental Accounting. 2004.

[13] Yuliana R. The Effect of Company Characteristics on the Extent of Corporate Social Responsibility (CSR) Disclosure and its Impact on Investor Reactions (Studies on Companies Listed on the IDX). Faculty of Economics, University of Brawijaya, 2008.

[14] Sayekti Y, Wondabio LS. Effect of CSR Disclosure on Earning Response Coefficient (An Empirical Study of Companies Listed on the Indonesia Stock Exchange. Account. Natl. Symp. X, Hasanuddin Univ. Makassar., 2007.

[15] Chwastiak M, Young JJ. Silences in annual reports. Crit Perspect Account 2003;14:533-52. doi:10.1016/S1045-2354(02)00162-4.

[16] Ambadar J. CSR in Practice in Indonesia. Jakarta: PT. Gramedia; 2008.

[17] Mulawarman AD, Kamayanti A. Towards Islamic Accounting Anthropology: How secular anthropology reshaped accounting in Indonesia. J Islam Account Bus Res 2018;9:629-47. doi:10.1108/JIABR-02-2015-0004.

[18] Kusdewanti A. Teori ketundukan: Gugatan atas agency theory. Yayasan Rumah Peneleh. Seri Media dan Literasi; 2016.

[19] Crowther D. Social and Environmental Accounting. United Kingdom: Pearson Education Inc; 2000.

[20] Dewi IGAAO. Dialectics and Critical Reflections on the Reality of "Sustainability" in Sustainability Reporting Practices: A Habermasian Narrative. Indones J Account Financ 2010;7:139-52.

[21] Capra F. The Turning Point: A New Vision of Reality. Futurist 1982. doi:CBClipping.

[22] Kamayanti A. Metodologi Penelitian Kualitatif Akuntansi: Pengantar Religiositas 
Keilmuan (Edisi Revisi). Malang: Penerbit Peneleh; 2020.

[23] Dewi NWY. Social and Environmental Responsibility Reporting Model for Companies Owning Natural Tourism Exploitation Permits Based on the Tri Hita Karana Philosophy. Natl. Semin. Innov. Res. II, 2014.

[24] Rosenau PM. Postmodern and the social sciences: insights, inroads, and intrusions. vol. 1. New Jersey: Princeton University Press; 1992. doi:10.1017/CBO9781107415324.004.

[25] Triyuwono I, Djamhuri A, Mulawarman AD, Prawironegoro D. Philosophy of Accounting: Contemplative, Holistic, Intuitive, Imaginative, Creative, Rational, and Radical Thinking in Accounting. Mitra Wacana Media; 2016.

[26] Ahmed U. Postmodernism and Islam: Predicament and Promise. London and New York.: Routledge.; 1992.

[27] Mulawarman AD. Jang Oetama: Jejak dan Perjuangan HOS Tjokroaminoto. Yogyakarta: Galang Press; 2015.

[28] Burrell G, Morgan G. Sociological Paradigms and Organisational Analysis: Elements of the Sociology of Corporate Life. Great Britain: Arena; 1979.

[29] Chua WF. Radical Developments in Accounting Thought. Account Rev 1986;61:601-32.

[30] Sarantakos S. Social Research. Melbourne: Macmilan Education Australia; 1993.

[31] Mulawarman AD, Ludigdo U. Metamorfosis Kesadaran Etis Holistik Mahasiswa Akuntansi: Implementasi Pembelajaran Etika Bisnis dan Profesi Berbasis Integrasi IESQ. J Akunt Multiparadigma 2010;1:429-44.

[32] Mulawarman AD. Masa depan Ekonomi Islam: Dari Paradigma menuju Metodologi. IMANENSI 2013;1:1-13.

[33] Zulkifli. The Doctrine of Love in the Traditions of Major Religions: Between Theory and Practice. Lmu Ushuluddin 2016;5:189-200.

[34] Mulawarman AD. Pendidikan Akuntansi Berbasis Cinta: Lepas dari Hegemoni Korporasi Menuju Pendidikan yang Memberdayakan dan Konsepsi Pembelajaran yang Melampaui. EKUITAS (Jurnal Ekon Dan Keuangan) 2008;12:142-58. doi:10.24034/j25485024.y2008.v12.i2.2066. 
This page is intentionally left blank 